\title{
6. Terrorism and Public Opinion in Australia
}

\author{
Juliet Pietsch and Ian McAllister
}

In contrast with many of the other advanced democracies, Australia has been relatively immune from acts of terrorism. The terrorist acts that have occurred in Australia over the past half-century generally involved attacks on foreign diplomats by ethnic extremists intent on publicising grievances within their home country. The most significant terrorist act on Australian soil took place in February 1977 during the Commonwealth Heads of Government meeting, when a bomb exploded outside the Hilton Hotel in Sydney, claiming three lives. By contrast, between 1968 and 1998 about 125 people were killed in mainland Britain by Irish republican violence, and in the United States, six were killed in the February 1993 World Trade Center bombing, 198 died in the Oklahoma City bombing and 2998 in the 9/11 attacks. In relative terms, to date Australia has escaped the major effects of domestic terrorism that have been felt in many other countries.

Notwithstanding the absence of a terrorist attack within Australia, public opinion has been subjected to the effects of terrorism by way of the Bali bombings on 12 October 2002. Taking place in a popular tourist destination, the bombings killed 202 people, 88 of them Australian. An Islamist group, Jemaah Islamiyah, was responsible and said that it had mounted the attacks as retaliation for Australian support for the US-led 'War on Terror'. While the Bali attacks occurred outside Australia, the event brought home to the Australian public the potential terrorist threat that exists from radical Islamic groups. It also highlighted the potential domestic threat from terrorist activity and began a debate about the countermeasures that might be required to reduce that threat.

This chapter looks at the way the Australian public has responded to increased threats of terrorism in Australia and across the region. Using the 2007 Australian Survey of Social Attitudes (AuSSA), we examine public concern about terrorism and support for curtailing civil and political rights to deal with terrorist suspects who are considered to be a threat to national security. We also examine the extent to which concerns about terrorism and how to counter it influence political ideology and political behaviour. Before we begin our empirical investigation of these questions, we examine the different understandings of terrorism and outline some of the underlying causes. 


\section{Terrorism and political violence}

What constitutes an act of terrorism, and how does it differ from other acts of violence? There are many different understandings of what constitutes terrorism (see Lentini 2003, 2008). While the threat of terrorism is a relatively new phenomenon in Australia, different versions of terrorism have existed for centuries. Britain, for example, has experienced terrorism for at least four decades, but Irish republican violence in Britain, in particular, stretches back at least as far as the late nineteenth century (see Hayes and McAllister 2001, 2005). Similarly, Israel has been dealing with the challenges of terrorism since its foundation as a state in 1949. Since the 9/11 attacks in New York, however, the threat of terrorism has spread more widely across the advanced democracies and has taken on a global dimension with the expansion of rapid communication and transnational networks. In line with the increasingly global nature of terrorism, there has been a significant increase in the level of government and academic interest in the threat of terrorism.

There are numerous definitions of what constitutes terrorism. A consistent divide is whether states are capable of engaging in terrorism or whether it applies only to individuals. Beau Grosscup (2006), for example, argues that the strategic bombing that is often used in state-sanctioned military campaigns should be labelled as terrorism. In addition, Grosscup argues that those powers which use strategic bombing have been able to monopolise definitions of terrorism (Grosscup 2006). Other scholars of terrorism studies have focused solely on individuals, and argued that terrorism is the use of threats or violence against innocent victims from nonstate actors who want to bring about political change or achieve political goals (Hoffman 1998; Lentini 2008). Given that terrorism has now taken on a global dimension in many different political contexts, some scholars argue that the concept of terrorism suffers from 'stretching', with different types of crime now viewed as terrorism (Weinberg, Pedahzur and Hirsch-Hoefler 2004).

Accounts examining the causes of terrorism are as varied as the definitions. Traditional explanations often regard terrorism as a legitimate political struggle by a minority group to secure their independence against a more powerful state or group of states. Such groups often feel they have suffered unfairly and they regard terrorism as the only means of drawing attention to their cause (Pedahzur 2005). For example, in a study of political violence in Thailand, Croissant (2007) observes that the causes of terrorism can be traced to a range of contentious religious, cultural, economic and political causes. He argues that in southern Thailand, the Muslim minority has only ever rebelled when the Muslims perceived their cultural identity as threatened by the Bangkokbased authorities. The rise of suicide terrorism has added a new dimension to explanations of terrorism, with Ami Pedahzur (2005) suggesting that terrorists who use suicide to kill innocent civilians often do so for redemption. 
Many scholars have argued that the absence of orderly institutions and accountable governance in weak and failed states heightens the risk of terrorism (see Newman 2007). Failed states are viewed by the advanced democracies as raising both humanitarian and strategic concerns; however, there is also considerable evidence that terrorist organisations take advantage of stable democratic states. In fact, the evidence shows that open societies with democratic governments are highly susceptible to violent conflict (Eubank and Weinberg 2008), as the presence of terrorist groups in Europe, the United States, India and Japan has demonstrated. There are also many states that are characterised by weak policies, institutions and governance, yet do not play host to terrorist organisations. In research on the presence of terrorist groups in Afghanistan, Sudan and Somalia, Newman has observed that while terrorism may operate in weak or failed states, it does not necessarily follow that the condition of failed statehood explains their presence (Newman 2007).

The definitions of and explanations for terrorism therefore vary widely; however, from the perspective of public opinion, there is more clarity about what constitutes a terrorist act. The news is presented by the mass media and interpreted by governments and interest groups. Viewed through the lens of the mass media, what does or does not constitute terrorism is rather clearer than any discussion of the definitions might imply. Moreover, the surveys show that respondents are always willing to proffer an opinion about the threat of terrorism or about measures designed to reduce that threat. This suggests that the widespread elite discussions about terrorism that took place after the Bali bombings clearly impacted on mass public opinion.

\section{Public concern about terrorism}

While there are many definitions and elite discussions about what constitutes terrorism, the data from the 2007 AuSSA cannot fully analyse how the public understands the concept of a terrorist attack. Our research, however, shows that respondents have no difficulty answering questions about terrorism and whether they feel it is a real or unlikely threat. First, terrorism did not rank highly as a main concern for the Australian public in the 2007 AuSSA. When asked to choose their first and second most important concerns from a list of 18 issues, just 3 per cent of the respondents ranked terrorism as the most important concern, making it tenth on the list. The most highly ranked issues were health care and hospitals (mentioned by 14 per cent), environmental damage (13 per cent), an ageing population (11 per cent) and lack of affordable housing (10 per cent). Nor was terrorism seen as a second-ranked issue, again being mentioned by just 3 per cent of respondents, making it twelfth out of the 18 issues. These results are similar to those found in the Australian Election Study (AES), where terrorism was mentioned as the most important issue by 5 per cent in 2001 and 2004, and by 2 per cent in 2007 (McAllister and Clark 2008, 53). 
Despite the public's low ranking of terrorism relative to other major issues, during 2007 it was still a concern for a significant proportion of the population. The 2007 AES found that 14 per cent of the respondents were 'very concerned' about being the victim of a terrorist attack, and a further 36 per cent was 'somewhat concerned'. ${ }^{1}$ These estimates were very close to those found in the United States, where about 44 per cent of survey respondents interviewed in June 2007 said that they were 'very' or 'somewhat' concerned that they or someone in their family could become the victim of a terrorist attack. ${ }^{2}$ Moreover, trend figures for the same question since November 2001 show that this proportion had remained remarkably consistent, varying little over the period, with the partial exception of a slight rise in public concern after the July 2005 London bombings.

By any standards, there is widespread public concern about the possibility of a terrorist attack. The 2007 AuSSA asked the respondents how likely they believed a terrorist attack was in South-East Asia and in Australia in the next 12 months. Table 6.1 shows that almost three-quarters of the respondents believed that it was likely that a major attack would take place in South-East Asia, with just 13 per cent seeing it as unlikely. This reflects concerns that South-East Asia during this period had become a regional centre for Islamic terrorism and an important hub for terrorist training and financial support. The 9/11 attacks appear to have been followed by an exponential growth in terrorist organisations dedicated to attacking the United States and other Western interests in the region. Substantially fewer respondents see an attack in Australia as likely; just more than one in three takes this view, with the largest proportion, 43 per cent, seeing such an attack as 'not very likely'.

\section{Table 6.1 Likelihood of a Terrorist Attack}

\begin{tabular}{lcc}
\hline & \multicolumn{2}{c}{ Terrorist attack in... } \\
& South-East Asia & Australia \\
\hline Very likely & 18 & 4 \\
Likely & 56 & 30 \\
Not very likely & 11 & 43 \\
Not at all likely & 2 & 11 \\
Don't know & 13 & 12 \\
Total & 100 & 100 \\
(N) & $(2516)$ & $(2523)$ \\
\hline
\end{tabular}

Note: The questions were - 'Do you think that a terrorist attack somewhere in [South-East Asia/Australia] during the next twelve months is...?'; 'And how concerned are you that there will be a major terrorist attack on Australian soil in the near future?'

Source: Australian Survey of Social Attitudes 2007, questionnaire C.

1 The question was: 'How concerned are you personally about you yourself or a family member being the victim of a future terrorist attack in Australia?' 
Overall, then, an attack in South-East Asia was seen as more than twice as likely as one in Australia. Despite the disparity in the proportions, the likelihood of seeing an attack in one region is strongly correlated with the likelihood of seeing an attack in another region. The correlation between the two items is high, at 0.473 ( $p<0.000)$, so the perception of a terrorist threat is only loosely related to a particular geographical region, in Australia or within the immediate region. This reflects the global nature of terrorism, and as terrorism has become transnational, so too have public perceptions about the threat that is associated with it. It also reflects the fact that the public's concern about terrorism has become what has been termed 'the new normal', or the sense that living with terrorism is an unavoidable part of everyday life (Bowman 2005, 4). For example, in 2003 about three-quarters of US respondents thought that living with terrorism would be a part of life in the future; the same figure in Australia in the 2007 AES was very similar, at 62 per cent. ${ }^{3}$

Are there any consistent patterns in the types of individuals who are more likely than others to be concerned about terrorism? Table 6.2 suggests that there are, at least with regards to gender, age and possessing a university education, and particularly with regards to the likelihood of an attack in South-East Asia. Women are more likely than men to see a terrorist attack in South-East Asia as likely - 25 per cent of women thought it was 'very likely' compared with 17 per cent of men - as are those aged over fifty. This reflects underlying gender and generational differences in attitudes to defence and foreign affairs more generally, with women and older persons being more likely to see threats to Australia (McAllister 2005, 33). Possessing a university education is also associated with a reduced probability of seeing a terrorist attack as likely, in both South-East Asia and Australia.

After 9/11 and the Bali bombings there was a consistent underlying concern about terrorism. While the public had immediate socioeconomic prioritiesmostly associated with health, education or the performance of the economythe fear of terrorism appeared to be a consistent background theme. The absence of a major terrorist act in Australia also underlines the extent to which the public is responding to events that have occurred internationally, in the United States, Britain, Spain or Indonesia, and to the global reach of the terrorist threat. It also highlights debates about the use of additional legal measures to counter these threats, and we examine this in detail in the next section.

3 The US figures are from Bowman (2005). The AES question was: 'Please say whether you strongly agree, agree, disagree or strongly disagree with each of the following statements. Acts of terrorism in Australia will be part of life in the future.' 
Australia: Identity, Fear and Governance in the 21 st Century

Table 6.2 Concern about Terrorism and Socioeconomic Status

\begin{tabular}{|c|c|c|c|c|}
\hline & Very likely & Likely & Not very likely & Not at all likely \\
\hline \multicolumn{5}{|c|}{ (Terrorist attack in South-East Asia) } \\
\hline \multicolumn{5}{|l|}{ Gender } \\
\hline Male & 17 & 67 & 14 & 2 \\
\hline Female & 25 & 60 & 13 & 2 \\
\hline \multicolumn{5}{|l|}{ Age } \\
\hline $18-34$ & 14 & 62 & 21 & 3 \\
\hline $35-49$ & 19 & 66 & 13 & 2 \\
\hline $50-64$ & 26 & 63 & 9 & 2 \\
\hline 65 or over & 20 & 65 & 14 & 1 \\
\hline \multicolumn{5}{|c|}{ University education } \\
\hline $\begin{array}{l}\text { No university } \\
\text { education }\end{array}$ & 22 & 64 & 12 & 2 \\
\hline $\begin{array}{l}\text { University } \\
\text { education }\end{array}$ & 16 & 65 & 17 & 2 \\
\hline \multicolumn{5}{|c|}{ (Terrorist attack in Australia) } \\
\hline \multicolumn{5}{|l|}{ Gender } \\
\hline Male & 5 & 38 & 47 & 10 \\
\hline Female & 4 & 29 & 52 & 15 \\
\hline \multicolumn{5}{|l|}{ Age } \\
\hline $18-34$ & 3 & 31 & 51 & 15 \\
\hline $35-49$ & 5 & 33 & 51 & 11 \\
\hline $50-64$ & 6 & 37 & 45 & 12 \\
\hline 69 or over & 4 & 33 & 51 & 12 \\
\hline \multicolumn{5}{|c|}{ University education } \\
\hline $\begin{array}{l}\text { No university } \\
\text { education }\end{array}$ & 5 & 37 & 47 & 11 \\
\hline $\begin{array}{l}\text { University } \\
\text { education }\end{array}$ & 3 & 25 & 55 & 17 \\
\hline
\end{tabular}

Note: 'Don't know' responses have been excluded.

Source: Australian Survey of Social Attitudes 2007, questionnaire C.

\section{Countering the threat of terrorism}

Since the 9/1 1 attacks in the United States, most Western societies have introduced a range of counter-terrorism legislation to manage the risk of terrorist attacks and deter future attacks. There are two dominant approaches to counter-terrorism: one based on a criminal justice model where terrorism is viewed as a crime, the other approach a military model where terrorism is viewed as an act of warfare and the response requires the military and the curtailing of individual freedoms 
(Chalk 1998). Historically, Australia's approach to counter-terrorism has been guided by the criminal justice model and the use of the police force; however, the boundaries between the criminal justice model and the military model are not always clear during times of heightened threat (Crelinsten 1998; Crelinsten and Schmid 1992; Pedahzur and Ranstorp 2001). Indeed, Australia expanded its military operations in Afghanistan to combat the threat of terrorism and the government has stated that the responsibilities of the military and the police force must be merged in order to respond to terrorist threats (Australian Government 2008; Smith 2008).

The expansion of a criminal justice model has seen the introduction of special anti-terrorism legislation giving police and other authorities greater powers and resources to respond to terrorism. Since the 9/11 attacks in the United States and the Bali bombings in October 2002, Australia has made substantial increases to its budget on counter-terrorism strategy, with nearly $\mathrm{A} \$ 8$ billion having been committed since 2001 (Fealy and Borgu 2005). The most controversial part of Australia's counter-terrorism strategy was the introduction of antiterrorist legislation and amendments to existing acts passed since 2001. The new legislative measures involved expanded intelligence gathering and police powers, and an increase in the range of preventive detention and control orders that can be applied to terrorist suspects. The anti-terrorist legislation increased the powers of the State and federal police forces and security agencies such as the Australian Security and Intelligence Organisation (ASIO) to monitor, detain and charge suspected terrorists (see Goulder and Williams 2006; O'Neil 2007).

To what extent are these counter-terrorism measures supported by the public, and what part does concern about terrorism play in shaping those opinions? The answers to the first question appear in Tables 6.3 and 6.4, which show public opinion towards various measures designed to reduce the likelihood of a terrorist act occurring. A standard government response to terrorism is to allow for longer periods of detention than would be possible under normal criminal justice rules. The first parts of Tables 6.3 and 6.4 show that the majority of the survey respondents support this approach. Almost three in four agree that terrorist suspects should be imprisoned indefinitely, while 54 per cent believe that the government should have the right to detain suspects without trial. The slightly lower support for the latter reflects the fact that the question explicitly removes the requirement for a trial, while the former question does not.

Other powers that governments can take to counter terrorism include listening to telephone conversations and stopping and searching suspects. Again, in both cases, Table 6.4 shows that there is a majority in support of such measures, though more so for tapping telephones (which has support from 77 per cent of the respondents) than for stop and search (support from 54 per cent). Finally, interrogation methods used by the United States on terrorist suspects - notably, 'water-boarding', where prisoners 
have the sensation of drowning - have focused attention on the extent to which torture should be used to extract information from suspects. The second column in Table 6.3 shows that a majority see torture as never being justified, and only one in five sees torture as being justifiable to gain information.

Table 6.3 Support for Measures to Counter Terrorism

\begin{tabular}{lcc}
\hline & Imprison suspects indefinitely & Torture never justified \\
\hline Agree strongly & 38 & 29 \\
Agree & 35 & 32 \\
Neither & 8 & 16 \\
Disagree & 12 & 13 \\
Disagree strongly & 5 & 7 \\
Don't know & 2 & 3 \\
Total & 100 & 100 \\
(N) & $(2522)$ & (2507) \\
\hline
\end{tabular}

Note: The questions were - 'How much do you agree or disagree with the following statements? "If a man is suspected of planning a terrorist attack in Australia, the police should have the power to keep him in prison until they are satisfied he was not involved"; "Torturing a prisoner in an Australian prison is never justified, even if it might provide information that could prevent an attack".'

Source: Australian Survey of Social Attitudes 2007, questionnaire C.

\section{Table 6.4 Support for Extending Legal Measures to Counter Terrorism}

\begin{tabular}{lccc}
\hline & \multicolumn{2}{l}{ If person is suspected of terrorism, government should... } \\
& Detain without trial & Tap telephones & Stop and search \\
\hline $\begin{array}{l}\text { Definitely should } \\
\text { have right }\end{array}$ & 27 & 38 & 23 \\
$\begin{array}{l}\text { Probably should } \\
\text { have right }\end{array}$ & 27 & 39 & 31 \\
$\begin{array}{l}\text { Probably should not } \\
\text { have right }\end{array}$ & 23 & 14 & 24 \\
$\begin{array}{l}\text { Definitely should not } \\
\text { have right }\end{array}$ & 20 & 7 & 20 \\
$\begin{array}{l}\text { Can't choose } \\
\begin{array}{l}\text { Total } \\
\text { (N) }\end{array}\end{array}$ & 3 & 2 & 2 \\
\hline
\end{tabular}

Note: The questions were- 'Suppose the government suspected that a terrorist act was about to happen. Do you think the authorities should have the right to... detain people for as long as they want without putting them trial?...tap people's telephone conversation?...stop and search people in the street at random?'

Source: Australian Survey of Social Attitudes 2007, questionnaire A.

These results show that a majority of the public will accept some infringement of their civil liberties in order to reduce the threat of terrorism. This contrasts sharply with similar results from the United States, which show that the American public is less willing than their Australian counterparts to accept restrictions on their civil liberties in the interests of countering terrorism. For 
example, when asked in a December 2006 survey 'In order to curb terrorism in this country, do you think it will be necessary for the average person to give up some civil liberties, or not?', 40 per cent said it would be necessary, but 54 per cent said that it would not be necessary, and 6 per cent were unsure. ${ }^{4}$ Similarly, in a September 2008 survey, 51 per cent said that they were more concerned about restrictions on their civil liberties than about the failure of the government to enact anti-terrorism legislation. These differences reflect the essentially rights-based political culture of the United States, where individual liberty is paramount, compared with the utilitarian culture of Australia, where efficiency in dealing with problems takes precedence over individual rights.

To what extent are the public's views about curtailing liberty to deal with terrorism influenced by perceptions of an imminent terrorist threat? Table 6.5 shows the correlations between the two questions measuring concern about a terrorist attack in South-East Asia and in Australia, and the public's views about detaining suspects indefinitely, and about the use of torture. All four correlations are significant, but they are particularly strong for concern about a terrorist threat and the detention of suspects. By contrast, those who see torture as never being justified are less concerned about a threat, but the relationship is only about one-third of that for indefinite detention. Clearly, then, those who are concerned about a terrorist attack see it as justifiable to take legal measures to reduce that threat, such as the indefinite detention of terrorist suspects.

\section{Table 6.5 Concern about Terrorism and Methods to Reduce the Threat}

\begin{tabular}{lcc}
\hline & $\begin{array}{c}\text { Imprison suspects } \\
\text { indefinitely }\end{array}$ & $\begin{array}{c}\text { Torture never } \\
\text { justified }\end{array}$ \\
\hline Attack likely in South-East Asia & $0.22(p<0.000)$ & $-0.07(p=0.002)$ \\
Attack likely in Australia & $0.33(p<0.000)$ & $-0.10(p<0.000)$ \\
\hline
\end{tabular}

Note: Figures are Pearson correlations, with significance level in parentheses.

Source: Australian Survey of Social Attitudes 2007, questionnaire C.

Countering terrorism represents a trade-off between increased security and curtailing civil liberty. At the core of the dilemma is the degree to which a democracy can contain terrorism and manage the associated risks while at the same time preserving liberal-democratic values (Pedahzur and Ranstorp 2001; Wilkinson 1986). In general, the more intrusive the nature of the counterterrorism strategy, the greater is the risk that democratic foundations will be compromised in the process (Pedahzur and Ranstorp 2001). Mani (2006) notes, however, that citizens will generally accept some restrictions on civil and human rights for the purpose of national security, but only if these restrictions are in conformity with the rule of law. The results shown here support that

4 <http://www.pollingreport.com/terror.htm> accessed 5 March 2009. 
interpretation, and there is most public support for extending measures that already are in place, such as tapping telephones. Moreover, these opinions are substantially driven by concerns about a terrorist attack; should such an attack occur on Australian soil then we would expect substantially more public support for a wider range of measures.

\section{Terrorism and political preferences}

There is a growing body of scholarship on the relationship between the threat of terrorism and public opinion. A number of studies have shown that there is a strong relationship between threat perceptions and public opinion (Arian 1989; Huddy et al. 2002, 2005). Terrorist threat perceptions, public opinion and support for public policy are often linked to underlying factors such as high media exposure, global experience and political knowledge (Ridout, Grosse and Appleton 2008). Similarly, studies have demonstrated the ways in which threat perceptions associated with terrorism influence political preferences and support for public policy generally (see Hutchinson and Gibler 2007). For instance, Pape $(2003,2005)$ observes that in Western democracies, an electorate that is sensitive to terrorism may call for greater concessions to terrorist groups. Other scholars have shown there is direct evidence between the incidence or threat of terrorism and the electorate's political preferences and levels of support for public policy (Berrebi and Klor 2006; McAllister 2008).

Research has shown that the threat of terrorism may have direct effects on political attitudes. In a study of Israeli voter sensitivity to terrorism, Berrebi and Klor (2006) identified two main political consequences of terrorism. The first consequence was for policy voting, so that voters changed their policy preferences in direct response to terrorism. The second consequence was in the ideological polarising effects within the electorate. Berrebi and Klor found that terrorism caused an increase in the relative support for political parties from the right end of the political spectrum, which place more weight on terrorism-deterrence policies. In addition, their conclusions supported the idea that terrorism polarises the electorate (Berrebi 2008). For example, their study showed that terrorism causes an increase in support for the right bloc in all localities with right-leaning preferences and a decrease in support for the right bloc in all localities with left-leaning preferences. ${ }^{5}$ Overall, their study provided strong empirical support for the hypothesis that the electorate is highly sensitive to terrorism.

5 The occurrence of a terrorist fatality within three months of an election is significantly associated with a 0.45 percentage point increase in the locality's relative electoral support for the right bloc of political parties. If the attack resulted in three fatalities, this would result in an increase of 1.35 percentage points. This could be enough to decide an electoral outcome (see Berrebi 2008). 
In the United States, research has shown that the threat of terrorism can alter public opinions in much the same way as wars can evoke popular feelings of hope and national pride. This 'rally round the flag' effect, as John Mueller (1973) has termed it, can in turn shape levels of confidence in government institutions and garner support for public policy (Gross, Brewer and Aday 2009). In Australia, studies have also shown that there are important links between public perceptions of threats from terrorism and support for public policy. For example, drawing on results from 1987-2007 AES surveys, McAllister observes that those who see more threats existing are more likely to view the ANZUS alliance with the United States as important than those who see fewer threats. In addition, those who perceive more threats within the region are more likely to have specific views about defence policy and support an increase in defence spending (see McAllister 2008, 13-14).

Notwithstanding these studies, it is difficult to determine whether it is one's political orientation that shapes attitudes towards policies designed to counter terrorism or whether the fear of terrorism itself is enough to shift one's ideological position further to the left or right. In general, however, the results of the AuSSA show that there is a strong relationship between ideological position and attitudes towards terrorism, measured by the person's self-placement on a zero-to-10 scale. ${ }^{6}$ For example, 21 per cent of those who see themselves on the political left view a terrorist attack in Australia as likely compared with 39 per cent who view themselves as centre-right. Those who put themselves in the political centre are most likely to see an attack as likely, at 46 per cent. In terms of whether terrorist suspects should be imprisoned indefinitely, those on the left are least supportive of the measure, with just 38 per cent supporting it. This compares with support for the measure from nine out of every 10 who place themselves on the political right. Very clearly, then, attitudes towards terrorism are influenced by political orientation.

6 The correlation between ideological position and the likelihood of a terrorist attack is $0.12(\mathrm{p}<0.000)$ and with detaining terrorist suspects, $0.40(\mathrm{p}<0.000)$. 


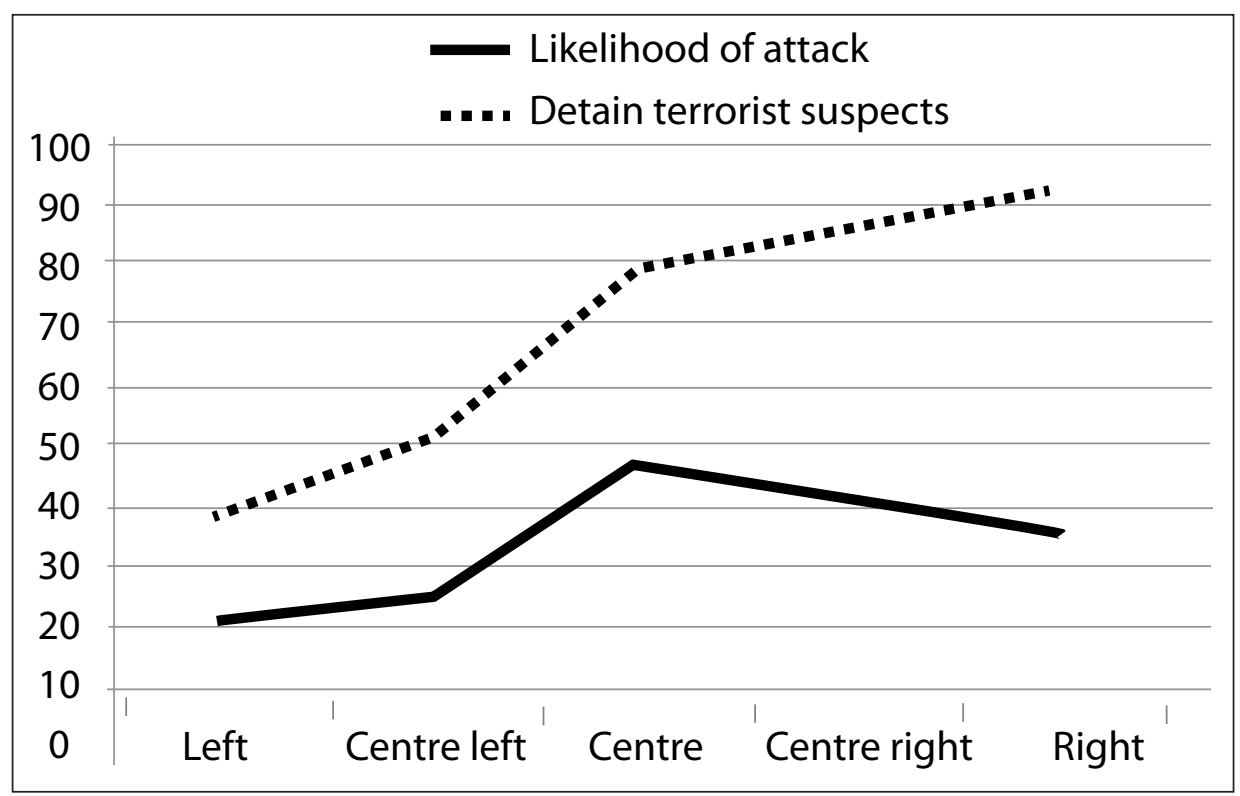

Figure 6.1 Ideological Position and Attitudes Towards Terrorism

Notes: Ideological location is left $(1,2,3)$, centre-left $(4,5)$, centre $(6)$, centre-right $(7,8)$, right $(9,10$, 11). Likelihood of attack in Australia combined 'Very likely' and 'Likely', and detain terrorist suspects is 'Strongly agree' and 'Agree'.

Source: Australian Survey of Social Attitudes 2007, questionnaire C.

\section{Conclusion}

Following the 9/1 1 attacks and the Bali bombings, the Australian public rapidly became aware of the potential of terrorism. Like the mass publics of most other advanced democracies, in Australia terrorism became the 'new normal', and formed a low priority but nevertheless consistent concern for a large proportion of the population. Research shows that low-probability, high-risk events such as a major terrorist attack produce significant changes in attitudes and behaviours among mass publics (Gigerenzer 2006). Australia has been no exception to this pattern. Our findings show widespread public concern about terrorism, with relatively little distinction being made between terrorist events occurring within Australia and within the region. That may reflect the global reach of modern terrorism, but it is also a consequence of the Bali bombings, which occurred overseas but had major implications for public perceptions of the problem and for national security policy.

The survey results also show strong support for countermeasures to reduce the terrorist threat. There is most support for extending current legal measures, 
such as tapping telephones or the indefinite imprisonment of suspects, and least support for measures that could be construed as torture. Indeed, the Australian public seems more supportive of a wide range of legal countermeasures than the US public, with the latter more concerned about the risks such changes hold for their civil and political rights. These measures are strongly associated with perceptions of the potential threat of terrorism, so that the more the public sees there to be a threat - realised or not - the stronger is the support for measures to deal with it. Finally, our results confirm the strong influence of political ideology on attitudes towards terrorism, in the form of support for or opposition to the imprisonment of suspects. Those who support such moves are more likely to place themselves on the political right, while those who oppose them place themselves on the political left.

What implications do these findings have for public policy towards terrorism? First, there is widespread support for the steps that the government has already taken to reduce the threat. The 2007 AES found that 51 per cent of those interviewed said that the government was doing all it could, with 39 per cent saying that it could do more. That support could evaporate rapidly, however, if a terrorist attack occurred and if it was shown that the government could have done more to prevent it. A further complicating factor is the increasing unpopularity of the wars in Iraq and Afghanistan, which were originally justified as a means of reducing the terrorist threat to Australia. The 2004 and 2007 AES surveys both showed that a majority of the public actually believed that Australian participation in these wars had increased, not reduced, the terrorist threat (McAllister 2008, Table 3).

A second implication for public policy stems from the random nature of terrorism. Research conducted after World War II in both Britain and Germany found that it was the indiscriminate nature of the aerial bombing that produced the most fear within the civilian population, even though the risk of death or injury was comparatively small (Jones et al. 2006). Moreover, over-energetic attempts by the authorities to counter the threat only exacerbated that fear. Terrorism induces similar fears to aerial bombing within the mass public by virtue of its random, unpredictable nature and by public awareness campaigns by the authorities aimed at limiting its effects. Balancing the need for public awareness of the potential terrorist threat against the possible panic such measures can induce represents the heart of the public policy challenge for government.

\section{References}

Arian, Asher. 1989. 'A people apart: coping with national security problems in Israel'. Journal of Conflict Resolution 33(4): 605-31. 
Australian Government. 2008. The National Security Practice Note: The Rudd Government's evolving national security agenda. Canberra: Australian Homeland Security Research Centre. <http://www.homelandsecurity.org. au/files/NSPN_Rudds_new_national_security_agenda08.pdf $>$ accessed 22 February 2009.

Berrebi, Claude. 2008. 'Are voters sensitive to terrorism? Direct evidence from the Israeli electorate'. American Political Science Review 102(3): 279-301.

Berrebi, Claude and Klor, Esteban. 2006. 'On terrorism and electoral outcomes: theory and evidence from the Israeli-Palestinian conflict'. The Journal of Conflict Resolution 50(December): 899-925.

Bowman, Karlyn. 2005. US Public Opinion and the Terrorist Threat. Washington, DC: Canada Institute. <http://www.wilsoncenter.org/index.cfm?topic_ id=1420\&fuseaction=topics. public $>$ accessed 5 March 2009.

Chalk, Peter. 1998. 'The response to terrorism as a threat to liberal democracy'. Australian Journal of Politics and History 44(3): 373-88.

Crelinsten, Ronald. 1998. 'The discourse and practice of counter-terrorism in liberal democracies'. Australian Journal of Politics and History 44(1): 389413.

Crelinsten, Ronald and Schmid, Alex. 1992. 'Western responses to terrorism: a twenty-five year balance sheet'. Terrorism and Political Violence 4(4): 307-40.

Croissant, Aurel. 2007. 'Muslim insurgency, political violence and democracy in Thailand'. Terrorism and Political Violence 19(1): 1-18.

Eubank, William and Weinberg, Leonard. 2008. 'Terrorism and democracy: perpetrators and victims'. Terrorism and Political Violence 13(1): 155-64.

Fealy, Greg and Borgu, Aldo. 2005. Local Jihad: Radical Islam and terrorism in Indonesia. Canberra: Australian Strategic Policy Institute. <http://www.aspi. org.au/publications/publication_details.aspx?ContentID $=79 \&$ pubtype $=5 .>$ accessed 20 January 2009.

Gigerenzer, Gerd. 2006. 'Out of the frying pan into the fire: behavioral reactions to terrorist attacks'. Risk Analysis 26(2): 347-51.

Goulder, Ben and Williams, George. 2006. 'Balancing national security and human rights: assessing the legal response of common law nations to the threat of terrorism'. Journal of Comparative Policy Analysis 8(1): 43-62. 
Gross, Kimberly, Brewer, Paul and Aday, Sean. 2009. 'Confidence in government and emotional responses to terrorism after September 11, 2001'. American Politics Research 37(1): 107-28.

Grosscup, Beau. 2006. Strategic Terror: The politics and ethics of aerial bombardment. London: Zed Books.

Hayes, Bernadette and McAllister, Ian. 2001. 'Sowing dragon's teeth: public support for political violence and paramilitarism in Northern Ireland'. Political Studies 49(5): 901-22.

Hayes, Bernadette and McAllister, Ian. 2005. 'Public support for political violence and paramilitarism in Northern Ireland'. Terrorism and Political Violence 17(4): 599-617.

Hoffman, Bruce. 1998. Inside Terrorism. New York: Columbia University Press.

Huddy, Leonie, Feldman, Stanley, Capelos, Theresa and Provost, Colin. 2002. 'The consequences of terrorism: disentangling the effects of personal and national threat'. Political Psychology 23: 485-509.

Huddy, Leonie, Feldman, Stanley, Taber, Charles and Lahav, Gallya. 2005. 'Threat, anxiety, and support of antiterrorism policies'. American Journal of Political Science 49: 593-608.

Hutchinson, Marc and Gibler, Douglas. 2007. 'Political tolerance and territorial threat'. The Journal of Politics 69(1): 128-42.

Jones, Edgar, Woolven, Robin, Durodié, Bill and Wessely, Simon. 2006. 'Public panic and morale: Second World War civilian responses re-examined in the light of the current anti-terrorist campaign'. Journal of Risk Research 9: 57-73.

Kiewiet, Roderick. 1981. 'Policy-oriented voting in response to economic issues'. American Political Science Review 75(June): 448-59.

Lentini, Pete. 2003. 'Terrorism and its (re)sources: a review article'. Australian and New Zealand Journal of Criminology 36(3): 368-78.

Lentini, Pete. 2008. 'Understanding and combating terrorism: definitions, origins and strategies'. Australian Journal of Political Science 43(1): 133-40.

McAllister, Ian. 2005. Attitude Matters. Public opinion towards defence and security. Canberra: Australian Strategic Policy Institute.

McAllister, Ian. 2008. Public Opinion in Australia Towards Defence, Security and Terrorism. Canberra: Australian Strategic Policy Institute. 
Australia: Identity, Fear and Governance in the 21 st Century

McAllister, Ian and Clark, Juliet. 2008. Trends in Australian Political Opinion: Results from the Australian Election Study, 1987-2007. Canberra: Australian Social Science Data Archive.

Mani, Rama. 2006. The Relationship between Security and Democracy in Combating Terrorism. Doha, Qatar: United Nations Development Programme.

Mueller, John E. 1973. War, Presidents, and Public Opinion. New York: John Wiley.

Newman, Edward 2007. 'Weak states, state failure, and terrorism'. Terrorism and Political Violence 19(4): 463-88.

O'Neil, Andrew. 2007. 'Degrading and managing risk: assessing Australia's counter-terrorist strategy'. American Journal of Political Science 42(3): 471-87.

Pape, Robert. 2003. 'The strategic logic of terrorism'. American Political Science Review 97(August): 343-61.

Pape, Robert. 2005. Dying to Win: The strategic logic of suicide terrorism. New York: Random House.

Pedahzur, Ami. 2005. Suicide Terrorism. Cambridge, Mass.: Polity Press.

Pedahzur, Ami and Ranstorp, Magnus. 2001. 'A tertiary model for countering terrorism in liberal democracies: the case of Israel'. Terrorism and Political Violence 13(2): 1-26.

Ridout, Travis, Grosse, Ashley and Appleton, Andrew. 2008. 'News media use and Americans' perceptions of global threat'. American Journal of Political Science 38(4): 575-93.

Smith, Ric. 2008. Summary and Conclusions: Report of the review of homeland and border security. Canberra: Australian Government.

Weinberg, Leonard, Pedahzur, Ami and Hirsch-Hoefler, Sivan. 2004. 'The challenges of conceptualising terrorism'. Terrorism and Political Violence 16(4): 777-94.

Wilkinson, Paul. 1986. Terrorism and the Liberal State. Basingstoke, UK: Macmillan. 